\begin{tabular}{|ccc}
\hline Sournals & $\begin{array}{c}\text { INTERNATIONAL JOURNAL OF } \\
\text { ORGANIZATIONAL LEADERSHIP }\end{array}$ & $\begin{array}{c}\text { INDUSTRIAL } \\
\text { MANAGEMENT } \\
\text { INSTITUTE }\end{array}$ \\
\hline \hline
\end{tabular}

\title{
Determinants of corporate cash holdings in Pakistan
}

\author{
Mohsin Shabbir ${ }^{1}$, Shujahat Haider Hashmi ${ }^{2 *}$, Ghulam Mujtaba Chaudhary ${ }^{3}$ \\ ${ }^{1,2}$ CUST, Islamabad, Pakistan \\ ${ }^{3}$ UMSIT, Kotli (AJK), Pakistan
}

\begin{tabular}{l}
\hline \\
Keywords: \\
Cash Holdings, Pecking \\
Order Theory, Trade-Off \\
Theory \\
\hline Received \\
16 November 2015 \\
Received in revised form \\
14 February 2016 \\
Accepted \\
19February 2016 \\
\hline
\end{tabular}

Correspondence:

shujahat@cust.edu.pk

\section{Abstract}

\begin{abstract}
Corporate cash holdings always involve a trade-off between benefits and costs. This study investigates the determinants of corporate cash holdings. Cash flows, leverage, liquidity, cash flows volatility, profitability, growth opportunities, firm size, debt maturity, and dividend represent the independent variables in the research study. It is based on a panel data of 150 Pakistani non-financial listed firms on KSE during the period 2004-2012. Panel regression analysis has been conducted to determine the major factors affecting cash holdings. The results imply that growth opportunity, company size, cash flows, and profitability of the firms exert a positive effect while leverage and liquidity show a significant negative impact on corporate cash holding. The findings indicated that both pecking order theory and trade-off theory play an important role in explaining the determinants of corporate cash holdings. The findings are beneficial for managers, shareholders, investors, regulatory bodies, and researchers for developing appropriate policies.
\end{abstract}

CAIMI Journals

\section{Introduction}

During recent financial crises both media and business executives emphasized on the importance of adequate cash holding by the companies; cash is the life blood for a company and a company cannot survive its operations without it and every company holds a significant level of their current assets as cash reserves. Cash holding is important matter for a company 
because it provides them with liquidity. In general circumstances, the level of liquid assets (cash) which a non-financial company holds is associated with economic system and company's level of return. On the other hand, non-financial companies, operating in a fluctuating economic system and political instability, are examining to hold a much larger amount of liquid assets than they comparatively require. In previous literature cash is generally defined as cash and cash equivalents (Ferreira \& Vilela 2004; Kim, Mauer, \& Sherman, 1998; Opler, Pinkowitz, Stulz, \& Williamson, 1999). There are different views on the appropriate ratio of cash to run the business affairs smoothly. For example, Kalcheva and Lins (2007) found out that firms hold $16 \%$ of total assets in the shape of cash and cash equivalent. Guney, Ozkan, and Ozkan (2003) determined this average cash ratio as 14\%, Ferreira and Vilela (2004) calculated 15\%, Dittmar, Mahrt-Smith, and Servaes (2003) described approximately $13 \%$, and Al-Najjar and Belghitar (2011) concluded that the firms should hold an average of $9 \%$ in cash to total assets.

Companies must hold an optimal level of cash on hand for different reasons such as for investing in new infrastructure, dividend payments or share repurchases, survival during economic downturn, and dealing with unpredicted events. In several studies, it is found out that cash provides lower cost of financing for the company because increasing external financing is more expensive due to information asymmetry (Myers \& Majluf, 1984), agency problems (Myers, 1984), and asset substitution (Jensen \& Meckling, 1976). Therefore, managers are required to maintain adequate internal financial flexibility to reduce the costs related to external financing in imperfect capital markets.

There are other reasons related to corporate cash holding. The famous liquidity preference theory identifies three most important motives that non-financial companies uses to maintain an optimal level of cash holdings including transaction, reactionary, and speculative. The first motive of cash holding is related to the reduction of transaction cost to raise capitals and the requirement of liquidating current assets to make payments. For example, Miller and Orr (1966) investigated the brokerage cost could encourage companies to hold up larger liquid assets. On the other, Myers and Majluf (1984) suggested that the external capital is more expensive than that of internally generated capital due to imperfect information. The precautionary motive proposes that company must hold an appropriate level of cash reserves for the payment of unforeseeable events. Opler et al. (1999) analyzed that companies had a general trend to hold up a greater level of liquid asset if their industry has more volatility in cash flows. Similarly, Mikkelson and Partch (2003) also concluded that a company which continuously held larger cash funds might not underperform relative to their peer companies. The prior research studies recommend that companies normally utilize internally generating capital to hedge the future cash flow ambiguity and to enhance their cash holding in response to increase in cash flow volatility.

There are two most important theories used in previous literature for an explanation of corporate cash holdings that are trade-off theory and pecking order theory. In accordance with the trade-off theory, companies select their best level of the cash by comparing the cost and benefit of cash holding; managers want to maximize the shareholder wealth and they adjusting cash ratio in a way that the marginal cost of the cash holding is equal to the marginal benefit. On the other hand, pecking order theory of Myers and Majluf (1984) state that there is no best 
possible level of corporate cash holdings and cash just operate as a buffer between the investment needs and retained earnings. Moreover, this theory believes a financial hierarchy followed by the companies to reduce the costs of information asymmetries. For any new investment opportunity, company will prefer to finance through internal capital, then from debt and in the end with the equity.

Several studies have focused on the role of firm-specific variables as determinants of cash holding. For example, Opler et al. (1999) finds outs firms with more risky cash flows and good growth opportunities comparatively hold a larger cash ratio as compared to other firms. On the other hand, Kim, Kim, and Woods (1998) concluded that companies facing more cost of external financing, higher earnings volatility, and lower profitability held larger size of liquid assets. Faulkender and Wang (2006) showed that small and large companies perceived the costs and benefits of cash holdings in a different manner; small companies with high leverage and extra costs of financial distress also hold large cash level. Almeida, Campello, and Weisbach (2004) examined that financially constrained companies saved extra cash as compared to unconstrained companies. Therefore, this study focused upon the major determinant of cash holdings in Pakistani non-financial listed companies in KSE across the different firm size and industries. Moreover, we discussed the behavior of these different firms' specific factors that influence company's cash holdings decision. Thus, maintaining a particular level of liquidity in the company is important for smoothness of operation. The level of cash retention may be affected by its policies related to working capital requirements, corporate governance, capital structure, dividend payments, cash flows management, investment, and asset management (Al-Najjar, 2013; Dittmar \& Mahrt-Smith, 2007; Ferreira \& Vilela, 2004; Kim et al., 2011; Opler et al., 1999).

Most studies have been conducted in developed countries as stated earlier but these results cannot be generalized to developing and emerging economies like Pakistan that have unique economic problems and business conditions that may affect due to the political uncertainty, unstable security situation, and campaigns against extremism and energy crises; these dynamic nature of business environment conditions in Pakistan are very difficult as compared to those of any developed country in the world. Therefore, this study has focused on determining some important firm's specific factors influencing the appropriate level of cash holdings of Pakistani companies across dissimilar industries. A few studies have been carried out to explain the effect of these firm characteristics on cash holding in the context of Pakistan.

\section{The Literature Review}

Both the theoretical and empirical studies show that a number of factors influencing corporate cash holdings. Cash is the most liquid assets and it is determined by a company's capability to give its bills in time. Deficiency in cash or liquid assets may affect a company to lose its incentives given by its suppliers of credit and goods. Loss of the incentives can result in higher cost of goods that lower profitability of the business. Hence, companies want to retain a certain level of liquidity. On the other hand, there is no standard level for the liquidity. It depends on the nature of the business, level of operations, and the location of the company that operate and so many other factors. Companies holding a high level of cash and cash equivalents have drawn the interest of the researchers. For example, Cossin and Hricko (2004) explained that 
deciding upon the optimal level of cash provided for the best possible timing to make investment and avoid the underpricing problem. Gao, Harford, and Li (2013) argued that agency problems affect not only the target level of cash, but also how managers behave with cash in excess of the target.

There are several factors that affect the level of corporate cash holdings of the firm. One of most important factor is leverage that implies the proportion of debt in capital structure. Companies having ability to issue new debts hold less cash and it is used to fund new investment opportunity. Therefore, both the pecking order and trade-off theories predict negative relation between leverage and cash holding (Diamond, 1991; A. Ozkan \& N. Ozkan, N., 2004). Several studies have found negative relation between leverage and cash holding (Afza \& Adnan, 2007; Ferreira \& Vilela, 2004; Ogundipe, Salawu, \& Ogundipe, 2012; Shah, 2011). However, growing companies hold extra cash amount as compared to mature firms. Gill and Mathur (2011) and Al-Najjar (2011) found the similar results. Moreover, country-specific characteristics i.e. shareholder protection, ownership concentration, level of credit protection may moderate the relation between leverage and cash holding (Guney et al., 2007). There may exist non-linear relation between them and needs to be explored further. However, excessive level of debt also increases the probability of bankruptcy risk and companies may be compelled to hold extra cash to pay off debt. Thus, the direction of relation is not clearly determined (Opler et al., 1999). Therefore, we expect both positive and negative association between leverage and corporate cash holding.

\section{Research Hypotheses}

\section{$\mathrm{H}_{1}$ : Leverage has significant effect on cash holding.}

Firm size is another crucial factor that exerts negative effect on cash holding because companies are required to hold lesser amount of cash due to economies of scale (Bates, Kahle, \& Stulz, 2009). According to trade-off theory, cash holdings and firm size should have an inverse relation; because larger firms can earn profit from the economies of scale (Mulligan, 1997), more diversification, greater constant cash flows and a lower possibility of financial distress (Titman \& Wessels, 1988), get easy access to capital markets (Ferri \& Jones, 1979), and also decrease the borrowing cost and less likely to go bankrupt (Ferreira \& Vilela, 2004; Opler et al., 1999). On the other hand, the pecking order theory predicts positive relationship between the firm size and corporate cash holding because large companies usually do better as compared to small companies and for that reason, they must have extra cash (Opler et al., 1999). However, Ferreira and Vilela (2004) showed the contradictory results that small companies facing more growth opportunities and higher business risk tend to hold extra cash because it is highly expensive for small companies to increase capital in the borrowing markets. Some studies have also found no relation between firm size and cash holding. Moreover, companies operating in large competitive industries hold larger cash reserves as compared to other industries and the companies having large access to capital market raise funds from external investors. We expect either positive or negative effect of firm size on cash holding.

\section{$\mathrm{H}_{2}$ : Firm has significant effect on cash holding.}


Along with leverage and firm size, profitability also affects the level of cash retention by the companies. Profitable companies are expected to keep lesser amount of cash because of greater availability of cash flows from operations (Kim et al., 1998). According to the trade-off theory, there is negative correlation between cash holding and profitability; because a profitable firm has sufficient cash flows to avoid the underinvestment problems (Bates et al., 2009; Kim et al., 1998; A. Ozkan \& N. Ozkan, 2004). On the other hand, pecking order theory expects a positive relation between profitability and cash holding because cash is a result of financing and investment activities (Dittmar et al., 2003). Ferreira and Vilela (2004) and Almeida et al. (2004) also supported pecking order theory; because more profitable company has easy access to external capital market at lower cost, pay dividends to their shareholders, and repays their debt. Hence, they have tended to cumulate more cash to avoid against earnings unpredictability or short of liquidity. Thus, normal positive relationship exists among cash holding and profitability and we predict either positive or negative significant effect of profitability on cash holding.

\section{$\mathrm{H}_{3}$ : Profitability has significant effect on cash holding.}

The existence of more liquid assets in balance sheet besides cash and marketable securities also influence optimal cash holdings because they are considered alternative to cash. The costs of converting liquid assets into cash are very low as compared to other assets, as a result company with a more liquid asset is expected to hold lesser hoard cash. For example, Ferreira and Vilela (2004) showed if the firm was faced a cash shortage, liquid assets could easily liquidate and so they can be used as a substitute of cash. Several studies have therefore found inverse relation between liquidity and cash holdings (Ali \& Yousaf, 2013; Bates et al., 2009; Ferreira \& Vilela 2004; Gill \& Shah, 2012; Opler et al., 1999). Zeydabadinezhad, Sarokolaei, and Shoul (2013) found that liquidation of physical assets affects cash flow sensitivity regarding the limitations of financing.

\section{$\mathrm{H}_{4}$ : Liquidity has negative effect on cash holding.}

Companies also consider growth opportunities while optimizing the level of cash holding. Companies having more growth opportunities need to increase capital. Therefore, companies with more growth opportunities are expected to carry a higher level of investment into the liquid assets. Besides, companies with higher growth are observed to carry extra cash reserve (Al-Najjar \& Belghitar, 2011; Bates et al., 2009; Gill \& Mathur, 2011; Kariuki, Namusonge, \& Orwa, 2015; Kim et al., 1998; Kim et al., 2011; A. Ozkan \& N. Ozkan, 2004). Based on prior researches, we find positive effect of growth opportunities on cash holdings.

\section{$H_{5}$ : Growth has positive effect on cash holding.}

Cash flows also significantly affect companies to hold larger level of cash as a source of internal generated fund (Afza \& Adnan 2007; Al-Najjar \& Belghitar, 2011; Dittmar et al., 2003). Ferreira and Vilela (2004) found the positive relation between cash flows and cash holdings. On the other hand, Ogundipe et al. (2012) could not find a significant correlation between cash flows and cash holding of firm. Thus, we expect negative association between cash flows and cash holdings. Simple cash flows are not sufficient to measure its effect on cash 
holding; the volatility of cash flows also significantly affects the optimal level of cash holdings. Cash flows volatility implies the riskiness of cash flows; the higher the volatility is, the higher the cash ratio to be maintained by the companies (Al-Najjar \& Belghitar, 2011; Shah, 2011; Zeydabadinezhad et al., 2013).

\section{$\mathrm{H}_{6}$ : Magnitude of cash flows and its volatility has positive effect on cash holding.}

Debt maturity also influences the level of cash holdings because the use of more short-term debt forces the company to renew it on periodic basis; it puts pressure on the companies to hold higher amount of cash in case of repayment or insolvency (Guney et al., 2007). Ferreira and Vilela (2004) also found out that companies operating in better investor protection, hold lower level of cash. Therefore, we predict the negative effect of debt maturity on cash holdings of the firms.

\section{$\mathrm{H}_{\mathrm{S}}$ : Debt Maturity has negative effect on cash holding.}

Lastly, dividend payout pattern also significantly affects the cash holding level. The companies paying dividend are generally observed to be less risky and having greater access to capital market, therefore, the precautionary motive of cash holding is weak for dividend paying companies as compared to non-dividend paying companies (Afza \&Adnan, 2007; Opler et al., 1999). Moreover, Al-Najjar and Belghitar (2011), and Ullah, Rehman, Saeed, and Zeb (2014) showed that dividend paying companies held a lesser amount of cash. These studies found the negative relation between dividend payment and cash holdings. However, the positive relation is also found in some other studies. Kim et al. (2011) found the similar results that restaurant companies having a higher investment opportunity held larger cash reserves to meet their investment demands.

\section{$\mathrm{H}_{8}$ : Dividend has significant effect on cash holdings.}

Finally, it is assumed that dividend has significant impact on cash holdings.

\section{Methodology}

This section provides detail about variables description, hypothesis development, data sampling, data sources and collection, selection of appropriate econometric model, and data analysis. In this study, leverage, cash flow, cash flow volatility, firm size, grows opportunity, debt maturity, capital expenditure, and dividend are chosen as the explanatory variables based on literature review (Bates et al., 2009; Ferriar \& Vilela 2004; A. Okzan \& N. Okzan, 2004; Opler et al., 1999; Pinkowitz \& Williamsoor, 2001).

Firm size (FSZ) is defined as the natural logarithm of the book value of the company's total assets (Afza \& Adnan, 2007; Bates et al., 2009; Ferreira \& Vilela 2004; Opler et al., 1999). We expect a negative relation between cash holding and firm size. A profitable company would have relatively strong cash flows from its operating activities. The variable to capture the result of profitability in corporate cash holding is defined as return on equity (ROE). Therefore, it is expected a positive relationship between cash holding and profitability (PFT). The use of shortterm liability force company to periodically renew it (Ferreira \& Vilela, 2004; Guney et al., 2007). In this study, we measure maturity (DMT) as current liabilities over total liabilities and 
it is hypothesized a negative relation between cash holding and maturity of debt. The leverage (LEV) is measured as total debt and divided by the book value of total assets (Al-Najjar \& Belghitar, 2011; Ferreira \& Vilela, 2004; Kim et al., 1998; A. Ozkan \& N. Ozkan, 2004). We expect either positive or negative association between leverage and cash holding.

Cash flows (CFL) are measured as earnings before interest and taxes minus interest, taxes and common dividend and add back depreciation and amortization and then divide by total assets (Afza \& Adnan, 2007; Al-Najjar and Belghitar, 2011; Opler et al., 1999). It is expected a negative relationship between the cash holding and cash flows. Firms with higher volatility in cash flows faces a higher possibility of experiencing cash shortages and maintaining an adequate cash level allows the firm to utilize this money during rainy days. In this study, we measure cash flow volatility (CFV) as a standard deviation of company's cash flows divided by total assets over the period of the study (Afza \& Adnan, 2007; Al-Najjar \& Belghitar, 2011; Ferreira \& Vilela, 2004).

Companies with more liquid assets are expected to hold less cash. We determine net working capital (LQD) as current asset minus current liabilities and deduct the cash from the results (Afza \& Adnan, 2007; Ferreira \& Vilela, 2004; Kim et al., 1998; Opler et al., 1999; A. Ozkan \& N. Ozkan, 2002). Company with more growth opportunity is expected to hold a higher level of investments into the liquid assets. The market-to-book ratio is used as a proxy for a company's growth opportunity (GTH). Dividend payout ratio (DPO) has been used to check the impact of dividend payment on cash holding.

Cash reserve ratio $(\mathrm{CSH})$ is chosen as dependent variable. According to most of the previous studies (e.g. Dittmar et al., 2003; Ferreira \& Vilela 2004; Kalcheva and Lins, 2007; Opler et al., 1999) cash holding is defined as cash and cash equivalents over total assets. This measure the portion of a company's assets held in cash and this is the most conventional measure used in the previous literature. Table 1 gives detail of variables and their relations with both packing order and trade off theory.

Table 1

Variable Description and Theoretical Relation

\begin{tabular}{lll}
\hline Variables & Trade Off Theory & Pecking Order Theory \\
\hline Cash Flows (CFL) & Negative & Positive \\
Cash Flow Volatility (CFV) & Positive & Positive \\
Debt Structure (DMT) & Positive/Negative & Positive \\
Dividend Playout (DPO) & Positive/Negative & Positive \\
Firm Size (FSZ) & Negative & Positive \\
Growth Opportunity (GTH) & Positive & Positive \\
Leverage (LEV) & Positive/Negative & Negative \\
Liquidity (LQD) & Negative & Negative \\
Profitability (PFT) & Positive & Positive \\
\hline
\end{tabular}

This analysis requires firm specific annual data for dependent and independent variables taken from balance sheet analysis of listed companies in Karachi stock exchange which is published by State Bank of Pakistan. The data is used that covers the period from 2004 to 2012 . The sample size consists of companies related to the non-financial sector listed on Karachi 
Stock Exchange and is taken from different sectors such as textile sector, sugar sector, cement sector, engineering sector, paper and board sector, fuel and energy sector, chemical sector, transport industry, tobacco sector, jute sector, and food industry.

Our econometric model relates to panel data regression as we have companies' data over period. Therefore, we regress the cash holdings on firm size, cash flows, cash flows volatility, leverage, liquidity, profitability, growth opportunity, debt maturity, and dividend payout. The econometric equation is as follows:

$$
\begin{aligned}
& \text { CSHit }=\beta 0+\beta 1 \text { FSZit }+\beta 2 \text { PRFit }+\beta 3 \text { DMTit }+\beta 4 \text { LEVit }+\beta 5 \text { CFLit }+\beta 6 \text { CFVit }+ \\
& \beta 7 \text { LQDit }+\beta 8 \text { GTHit }+\beta 9 \text { DPOit }+\mathrm{e}_{\text {it }} \\
& \text { EQ. } 1
\end{aligned}
$$

Redundant F-test has been applied to choose among common and fixed effect. The following formula have been applied:

$$
\mathrm{F} \text {-value }=\left\{\left(\mathrm{R}^{2}-\mathrm{FE}-\mathrm{R}^{2}-\mathrm{CE}\right) /(\mathrm{N}-1)\right\} /\left\{\left(1-\mathrm{R}^{2}-\mathrm{FE}\right)(\mathrm{NT}-\mathrm{N}-\mathrm{K})\right\} \quad \text { EQ.2 }
$$

Where as:

$$
\begin{aligned}
& R^{2}-F E=R 2 \text { of the fixed effect model } \\
& R^{2}-C E=R 2 \text { of the common effect model } \\
& N=\text { Number of cross sections } \\
& T=\text { Number of time periods }
\end{aligned}
$$

We have applied common effect as the value of F-test is statistically insignificant (Fvalue $=0.00047 ; \mathrm{p}<0.05$ ) implying that firm level differences do not matter. Along with panel regression results, descriptive and correlation table is also given to get feel of data and check multicollinearity problem.

\section{Results}

In this chapter, the statistical results obtained will be discussed in terms of both research

\begin{tabular}{|c|c|c|c|c|c|}
\hline Variables & Mean & Median & Max & Min & SD \\
\hline $\mathrm{CSH}$ & 0.079 & 0.066 & 0.337 & 0.008 & 0.067 \\
\hline CFL & 0.077 & 0.080 & 0.090 & 0.054 & 0.012 \\
\hline CFV & 0.071 & 0.071 & 0.090 & 0.050 & 0.012 \\
\hline DPO & 0.350 & 0.321 & 0.689 & 0.251 & 0.099 \\
\hline LEV & 0.559 & 0.566 & 0.810 & 0.300 & 0.137 \\
\hline LQD & 0.007 & 0.019 & 0.790 & -0.585 & 0.206 \\
\hline GTH & 1.092 & 0.984 & 2.764 & 0.177 & 0.558 \\
\hline PFT & 19.053 & 21.159 & 80.025 & -17.701 & 18.916 \\
\hline DMT & 0.503 & 0.471 & 0.698 & 0.361 & 0.107 \\
\hline FSZ & 22.319 & 22.004 & 24.791 & 20.606 & 1.077 \\
\hline
\end{tabular}
hypothesis and the literature review in order to determine whether the support from the results is warranted to the mentioned capital structure theories and hypotheses based on the available evidence. The actual outcome of this study and the potential reasons of the observed outcomes are presented in Table 2 .

Table 2

Descriptive Statistics

Max= maximum value; Min= Minimum value; $S D=$ standard deviation 
Table 2 presents the main variables of this study and by applying the descriptive statistics give a general summary of the characteristics of the data. The cash ratio of Pakistani nonfinancial companies during the 2004-2012 has been 7.9\%. The similar result was found out by Shah (2011) using KSE data. Ogundipe et al. (2012) found out that Nigerian firms hold on the average $7 \%$ of cash to total assets. On the other hand, Al-Najjar and Belghitar (2011) observed that the firms held an average $9 \%$ in cash to total assets. However, this ratio is low from the cash ratio of companies in developed countries like UK and US. Opler et al. (1999) examined that US publicly traded firms held $17 \%$ of cash to total assets. Higher this value in their study may be due to normalization of cash and marketable securities by total assets minus cash and marketable securities rather than total assets. Kalcheva and Lins (2007) found that firms held $16 \%$ cash and cash equivalent of their total assets. Kim et al. (1998) observed that in their study cash to assets ratio was $8.1 \%$. The overall average market-to-book ratio is 1.0922 . This number represents a low level of growth opportunities for Pakistani companies in comparison with European and American companies that their market-to-book ratios were 1.71 and 1.53, respectively. Mean value of leverage is $55 \%$ which suggests that Pakistani companies have a trend to use higher amounts of debt to finance their assets as compared to the developed countries.

Table 3

Correlation Matrix

\begin{tabular}{|c|c|c|c|c|c|c|c|c|c|c|}
\hline Number & Variables & 1 & 2 & 3 & 4 & 5 & 6 & 7 & 8 & 9 \\
\hline 1 & CHL & 1 & & & & & & & & \\
\hline 2 & CFL & $0.128 * *$ & 1 & & & & & & & \\
\hline 3 & CFV & $0.17 *$ & $0.194 * *$ & 1 & & & & & & \\
\hline 4 & DPO & 0.116 & -0.043 & -0.085 & 1 & & & & & \\
\hline 5 & LEV & $-0.238^{* *}$ & 0.182 & $0.042 * *$ & 0.128 & 1 & & & & \\
\hline 6 & LQD & -0.091 & $0.278 * * *$ & $0.028^{*}$ & 0.123 & -0.447 & 1 & & & \\
\hline 7 & GTH & $0.373 * * *$ & 0.006 & -0.009 & 0.027 & -0.169 & -0.021 & 1 & & \\
\hline 8 & PFT & $0.494 * * *$ & $0.18 * *$ & 0.067 & 0.104 & -0.149 & 0.064 & $0.183^{* *}$ & 1 & \\
\hline 9 & DMT & -0.111 & 0.051 & 0.068 & 0.033 & -0.190 & 0.162 & -0.006 & -0.014 & 1 \\
\hline 10 & FSZ & $0.144 * *$ & -0.011 & $0.077^{* *}$ & -0.119 & $0.32 * * *$ & $-0.21 * *$ & -0.002 & 0.054 & 0.018 \\
\hline
\end{tabular}

Table 3 shows the association between the dependent variable (cash to assets ratio) of Pakistani non-financing listed companies and its key explanatory variables. In the current study, the correlation between the explanatory variables is less than 0.50 implying no problem of multicollinearity. The sign in correlation coefficient is more confirmation of our expectation of the relationship of company cash holdings of the explanatory variables. Therefore, there is no multicollinearity issue among explanatory variables.

The panel data analysis has been applied to regress cash holdings upon explanatory variables for the intention of a test of the above mention hypothesis. Table 4 gives results of panel regression.

There is no autocorrelation problem in the model as the Durbin-Watson value is higher than 1.5 (i.e., $\mathrm{d}>1.5$ ). The value of adjusted $\mathrm{R}$ square is quite reasonable as all independent variables are explaining approximately 40 percent variation in cash holdings. Moreover, $\mathrm{F}$ value is highly significant which implies the fitness of model $(\alpha<0.05)$. 
Table 4

Panel Regression Analysis Predicting the Determinants of Cash Holdings

\begin{tabular}{|c|c|c|c|c|c|c|c|c|}
\hline Variables & D & Adj. $R^{2}$ & F & Sig. & B & SE & $\mathrm{T}$ & $\mathrm{p}$ \\
\hline Model & 1.798 & 0.403 & 10.303 & 0.001 & & & & \\
\hline Constant & & & & & -0.206 & 0.12 & -1.75 & 0.08 \\
\hline CFL & & & & & 0.254 & 0.45 & 0.57 & 0.57 \\
\hline $\mathrm{CFV}$ & & & & & $0.896^{* *}$ & 0.43 & 2.09 & 0.04 \\
\hline DPO & & & & & 0.068 & 0.05 & 1.31 & 0.20 \\
\hline LEV & & & & & $-0.146 * * *$ & 0.04 & -3.29 & 0.00 \\
\hline LQD & & & & & $-0.069 * *$ & 0.03 & -2.43 & 0.02 \\
\hline GTH & & & & & $0.030^{* * *}$ & 0.01 & 3.21 & 0.00 \\
\hline PFT & & & & & $0.001 * * *$ & 0.00 & 4.78 & 0.00 \\
\hline DMT & & & & & $-0.092 *$ & 0.05 & -1.90 & 0.06 \\
\hline FSZ & & & & & $0.011 * *$ & 0.01 & 2.22 & 0.03 \\
\hline
\end{tabular}

The beta coefficients given in the table shows the magnitude and significance of independent variables upon dependent variable. For example, beta value of cash flows volatility (CFV) is 0.896 which implies that one unit change in CFV causes 0.896 unit positive change in cash holdings. The calculated $t$-value of CFV is $2.09(t>1.96)$ which shows the significant positive effect of cash flows volatility on cash holdings of firm in Pakistan. Similarly, growth (GHH), profitability (PFT) and Firm size (FSZ) has positive significant effect $(\mathrm{p}<0.05)$ on cash holdings. On the other hand, leverage, liquidity and debt maturity has negative significant effect $(\mathrm{p}<0.05)$ on level of cash holdings.

\section{Discussion}

Cash flow volatility has a significant positive effect on the corporate cash holdings decisions of the Pakistan non-financial listed firms in KSE. The predicted relation between cash flows volatility and corporate cash holding is significantly positive which supports Trade-off theory to argument that companies with more cash flows volatility hold higher level of cash reserves as a buffer to increase the probability of insolvency during poor business conditions. The findings are consistent with the previous empirical research (Almeida et al., 2004; Ferreira \& Vilela, 2004; A. Ozkan \& N. Ozkan, 2004).

Leverage has a significant negative effect on the cash holdings of the Pakistani firms and which is consistent with previous studies (Afza \& Adnan, 2007; Baskin, 1987; Bates et al., 2009). The results of this study provides evidence that companies with high debt ratios have lower cash holdings.

A positive relationship between the firm size and corporate cash holding has been found. Firm size is one of the most significant determinants of the corporate cash holdings; small companies suffer more cruel information asymmetries and higher financial constraint. Firm size has a significant positive effect on the corporate cash holdings decisions of the Pakistani non-financial listed firms. The result of this study is in line with other research works (Bates et al., 2009; Kim et al., 1998; Kim et al., 2011; Ogundipe et al., 2012; Opler et al., 1999). 
Liquidity has a significant negative effect on the corporate cash holdings decisions of the Pakistani non-financial listed firms that is consistent with previous results (Ferreira \& Vilela, 2004; Gill \& Shah, 2012; Opler et al., 1999). The negative effect of liquidity variable support our hypothesis that the company with extra liquid assets would tend to decrease their cash holdings, because these liquid assets can be used as cash substitutes and easily be converted into cash.

Our results show a significant positive relationship between growth opportunities (proxy by the market-to-book ratio) and cash holdings. Growth opportunity has a significant positive effect on the corporate cash holdings decisions of the Pakistani non-financial listed firms that is consistent with previous findings (Ferreira \& Vilela, 2004; Opler et al., 1999). This study shows that Pakistani companies use big amount of internally generated cash funds to finance profitable projects, thus reducing the asymmetric information costs from the external financing. It means that Pakistani companies with high growth opportunities can hold significant level of cash to decrease the risk of financial distress because of their inability to raise capital externally.

The expected relationship between profitability and corporate cash holdings is positive. Profitability has a significant positive effect on the corporate cash holdings decisions of the Pakistani non-financial listed firms. The results support the pecking order theory. This indicates that profitable companies are more capable to give dividends and accumulate cash holdings (Al-Najjar \& Belghitar, 2011). Debt maturity has a moderately negative effect on the corporate cash holdings; it implies that firms having shorter maturities of debts in Pakistan prefer to hold higher level of cash ratio to meet repayment schedules and face the insolvency problem. Finally, there is no evidence of the impact of dividend payouts and cash flows on corporate cash holdings.

\section{Conclusion}

We have explored the determinants of the corporate cash holding using a panel data of nonfinancial listed firms in KSE during the period 2004-2012. Our main objective was to get some new perspective on the determinants of corporate cash holding in emerging market of Pakistan. Our results are similar to those reported in earlier literature and provide more insight about the determinants of corporate cash holdings. In this study, we have found out that both pecking order and trade-off theories play a significant role in explaining the determinants of corporate cash holding. Our result shows that the factors determining the corporate cash holdings in the both emerging countries as well as in developed countries are mostly similar. The finding of this study shows that growth opportunity, cash flow, firm profitability, and cash flow volatility of the firms exert a positive effect on corporate cash holdings. Firm size, leverage, and liquidity has a significant negative impact on cash holdings. The results also imply that the high cash holdings are related with lower level of debt in capital structure of the firms. There is no proof of the impact of debt maturity and dividend payouts on corporate cash holdings of Pakistani non-financial firm.

We have only investigated the Pakistani non-financial listed firms. Many other internal and external firm characteristics that may influence cash ratio as mentioned by previous authors, for example, inflation, financial crisis, agency cost, financial constraint, business condition, 
corporate governance, investor rights, shareholder protection, asymmetric information etc. should be incorporated into future research work.

\section{References}

Afza, T., \& Adnan, S. M. (2007). Determinants of corporate cash holdings: A case study of Pakistan. Proceedings of Singapore Economic Review Conference (SERC), Singapore: Singapore Economic Review and the University of Manchester (Brooks World Poverty Institute), 164.

Ali, A., \& Yousaf, S. (2013). Determinants of cash holding in German market. Journal of Business \& Management, 12(6), 2834.

Almeida, H., Campello, M., \& Weisbach, M. S. (2004). The cash flow sensitivity of cash. The Journal of Finance, 59(4), $1777-1804$.

Al-Najjar, B. (2013). The financial determinants of corporate cash holdings: Evidence from some emerging markets. International Business Review, 22(1), 77-88.

Al-Najjar, B., \& Belghitar, Y. (2011). Corporate cash holdings and dividend payments: Evidence from simultaneous analysis. Managerial \& Decision Economics, 32(4), 231-241.

Baskin, J. B. (1987). Corporate liquidity in games of monopoly power. The Review of Economics \& Statistics, 69(2), 312-319.

Bates, T. W., Kahle, K. M., \& Stulz, R. M. (2009). Why do US firms hold so much more cash than they used to? The Journal of Finance, 64(5), 1985-2021.

Cossin, D. \& Hricko, T. (2004). The benefits of holding cash: A real options approach. Managerial Finance, 30(5), 29-43

Diamond, D. W. (1991). Debt maturity structure and liquidity risk. The Quarterly Journal of Economics, 106(3), 709-737.

Dittmar, A., Mahrt-Smith, J., \& Servaes, H. (2003). International corporate governance and corporate cash holdings. The Journal of Financial \& Quantitative Analysis, 38(1), 111-133.

Dittmar, A., \& Mahrt-Smith, J. (2007). Corporate Governance and the value of cash holdings. Journal of Financial Economics, 83(3), 599--634.

Faulkender, M., \& Wang, R. (2006). Corporate financial policy and the value of cash. The Journal of Finance, 61(4), 19571990.

Ferreira, A. M., \& Vilela, S. A. (2004). Why do firms hold cash? Evidence from EMU countries. European Financial Management, 10(2), 295-319.

Ferri, M. G., \& Jones, W. H. (1979). Determinants of financial structure: A new methodological approach. The Journal of finance, 34(3), 631-644.

Gao, H., Harford, J., \& Li, K. (2013). Determinants of corporate cash policy: Insights from private firms. Journal of Financial Economics, 109(3), 623-639.

Gill, A., \& Mathur, N. (2011). Factors that influence corporate liquidity holdings in Canada. Journal of Applied Finance \& Banking, 1(2), 133-153.

Gill, A., \& Shah, C. (2012). Determinants of corporate cash holdings: Evidence from Canada. International Journal of Economics \& Finance, 4(1), 70-79.

Guney, Y., Ozkan, A., \& Ozkan, N. (2007). International evidence on the non-linear impact of leverage on corporate cash holdings. Journal of Multinational Financial Management, 17(1), 45-60.

Jensen, M. C., \& Meckling, W. H. (1976). Theory of the firm: Managerial behavior, agency costs and ownership structure. Journal of Financial Economics, 3(4), 305-360.

Kalcheva, I., \& Lins, K. V. (2007). International evidence on cash holdings and expected managerial agency problems. Review of Financial Studies, 20(4), 1087-1112.

Kariuki, S. N., Namusonge, G. S., \& Orwa, G. O. (2015). Determinants of corporate cash holdings: evidence from private manufacturing firms in Kenya. International Journal of Advanced Research in Management \& Social Sciences, 4(6), 15-33.

Kim, J., Kim, H., \& Woods, D. (2011). Determinants of corporate cash-holding levels: An empirical examination of the restaurant industry. International Journal of Hospitality Management, 30(3), 568-574.

Kim, C. S., Mauer, D. C., \& Sherman, A. E. (1998). The determinants of corporate liquidity: Theory and evidence. Journal of Financial \& Quantitative analysis, 33(03), 335-359. 
Mikkelson, W. H., \& Partch, M. M. (2003). Do Persistent Large Cash Reserves Hinder Performance? Journal of Financial \& Quantitative Analysis, 38(02), 275-294.

Miller, M. H., \& Orr, D. (1966). A model of the demand for money by firms. Quarterly Journal of Economics, 80, 413-435.

Mulligan, C. B. (1997). Scale economies, the value of time, and the demand for money: Longitudinal evidence from firms. Journal of Political Economy, 105(5), 1061-1079.

Myers, S. C. (1984). The capital structure puzzle. The Journal of Finance, 39(3), 574-592.

Myers, S. C., \& Majluf, N. S. (1984). Corporate financing and investment decisions when firms have information that investors do not have. Journal of Financial Economics, 13(2), 187-221.

Ogundipe, S. E., Salawu, R. O., \& Ogundipe, L. O. (2012). The determinants of corporate cash holdings in Nigeria: Evidence from general method of moments (GMM). World Academy of Science, Engineering and Technology, 61, 978-984.

Opler, T., Pinkowitz, L., Stulz, R., \& Williamson, R. (1999). The determinants and implications of corporate cash holdings. Journal of Financial Economics, 52(1), 3-46.

Ozkan, A., \& Ozkan, N. (2004). Corporate cash holdings: An empirical investigation of UK companies. Journal of Banking \& Finance, 28(9), 2103-2134.

Pinkowitz, L., \& Williamson, R. (2001). Bank power and cash holdings: Evidence from Japan. Review of Financial Studies, 14(4), 1059-1082.

Shah, A. (2011). The corporate cash holdings: Determinants and implications. African Journal of Business Management, 5(34), $12939-12950$

Titman, S., \& Wessels, R. (1988). The determinants of capital structure choice. Journal of Finance, 43(1), 1-19.

Ullah, H., Rehman, S., Saeed, G., \& Zeb, A. (2014). Corporate ownership structure and firm excess cash holdings: Evidenced from emerging markets, Pakistan. Abasyn Journal of Social Sciences, 7(2), 228-244.

Zeydabadinezhad, M., Sarokolaei, M. A., \& Shoul, A. (2013). The effect of assets' liquidation regarding the limitations of financing on cash flow sensitivity of cash. International Journal of Advanced Studies in Humanities \& Social Science, 1(5), $445-451$. 